\title{
FOOD INTAKE, CONVERSION AND SWIMMING ACTIVITY IN THE AIR-BREATHING CATFISH HETEROPNEUSTES FOSSILIS
}

\section{S. ARUNACHALAM, E. VIVEKANANDAN \& T. J. PANDIAN*}

Zoology Department, Madurai University P. G. Centre, Sri Palaniandavar Arts College, Palni, Tamilnadu, India

* Present address (for requesting reprints): Dr. T. J. Pandian, Dept. of Biological Sciences, Madurai University, Madurai 62502 I, India

Received August I8, 1975

Keywords: Air-breathing fish. Conversion of food. Specific Dynamic Action. Heteropneustes fossilis

\section{Introduction}

Pandian \& Vivekanandan (I976) and Vivekanandan (1976), who considered feeding rate and conversion efficiency estimates as parameters for assessing metabolic rates and efficiencies, observed that the obligatory airbreathing fish Ophiocephalus striatus, reared in aquaria containing different depths of water, swam longer or shorter distance to exhange atmospheric air; such a design of experiment permitted them to measure food intake, growth and sustained active metabolism on a long term basis. They found that the fish in deeper waters consumed significantly more food and swam longer distance dissipating more energy on metabolism and swimming activity. As an extension of these studies, this preliminary experiment was carried out in another air-breathing fish Heteropneustes fossilis.

\section{Material and methods}

Healthy individuals of $H$. fossilis $(20 \pm 3.8 \mathrm{~g} ; \mathrm{I} 7 \mathrm{~cm})$ were acclimatized to laboratory conditions and feeding schedules in the respective aquaria. For the experiments, cylindrical ( $20 \mathrm{~cm}$ diameter) aquaria (capacity: $15 \mathrm{l}$ ) were chosen to minimize swimming activity in horizontal direction. Three test series of individuals were exposed to 20,40 and $60 \mathrm{~cm}$ water depths (respective water volumes: 6 , I2 and I 8 1); they travelled about 2,5 or 7 times their total body length when they returned to the maximum depth available after each surfacing.
Each series comprised 2 groups; one was starved and the other was offered excess food twice a day, for a period of $2 \mathrm{hr}$ each; pieces of goat liver were used as food. Care was taken to collect unfed liver with a pipette causing least disturbance to the fish, and suitable corrections were made for fluids lost by the liver pieces during 2 hour feeding period. Faeces were collected by filtering the entire aquaria once in 3 days. The 'Sacrifice method' (Maynard \& Loosli, I962) was used for determining the water content of the test individuals of both groups in each series before commencement of experiments.

Experiments were conducted in a laboratory, where -except for feeding and observation-there was no disturbance. The number of visits to the surface by each test individual was observed for a known period of time (30 to $45 \mathrm{~min}$ ), 4 times a day at $7 \mathrm{am}, \mathrm{I} \mathrm{pm}, 7 \mathrm{pm}$ and I I $\mathrm{pm}$. The distance travelled per individual per day was estimated by multiplying the mean number of visits per unit observation time with twice the depth of water. Observations were made daily for a period of $2 \mathrm{I}$ days. Since observations were made on 3 individuals in each of the groups belonging to 3 different series, each value presented in Table I represents the average (swimming) performance of a minimum of 250 observations.

Following the Winkler method, estimates on dissolved oxygen content in each aquarium water were made every day at about 9 am. Partial pressure of oxygen $\left(\mathrm{Po}_{2}\right)$ was calculated considering $5.65 \mathrm{cc}$ per litre of oxygen as water-saturation point at $27^{\circ} \mathrm{C}$ (Welch, I948), which is equivalent to I $55 \mathrm{~mm} \mathrm{Hg}$ (Hughes \& Singh, I97 I). 


\section{Results and discussion}

\section{Changes in the $\mathrm{PO}_{2}$}

When kept in water and allowed free access to air, $H$. fossilis, an air-breathing fish, breaths from both media, the intervals between each surfacing are irregular and vary from a few minutes to $1 / 2 \mathrm{hr}$, and are related to oxygen pressure in the water and air (see also Hughes \& Singh, 1971). Since water was changed in each aquarium once in 3 days, the respective high oxygen pressure $\left(\mathrm{Po}_{2}\right)$ was as high as $139 \mathrm{~mm} \mathrm{Hg}$ on that day (Table I). The $\mathrm{Po}_{2}$ decreased to different levels in the tested aquaria containing feeding or starving groups on the Ist and 2nd day; for instance, it decreased only to about $\mathrm{I}$ i $8 \mathrm{~mm} \mathrm{Hg}$ on the 2nd day in the aquaria containing starving groups exposed to different depths; among the feeding groups, there were significant decreases to 34,56 and $57 \mathrm{~mm} \mathrm{Hg}$ in the aquaria containing $20,40,60 \mathrm{~cm}$ depth of water on the 2 nd day,

Table 1. Surfacing activity as function of oxygen pressure $\left(\mathrm{Po}_{2}\right)$ in the feeding and starving Heteropneustes fossilis exposed to different water depths. Each value represents the average performance of minimum 3 individuals (mean $\pm \mathrm{SD}$ ) observed on 7 different dates for a period of 3 hours/day.

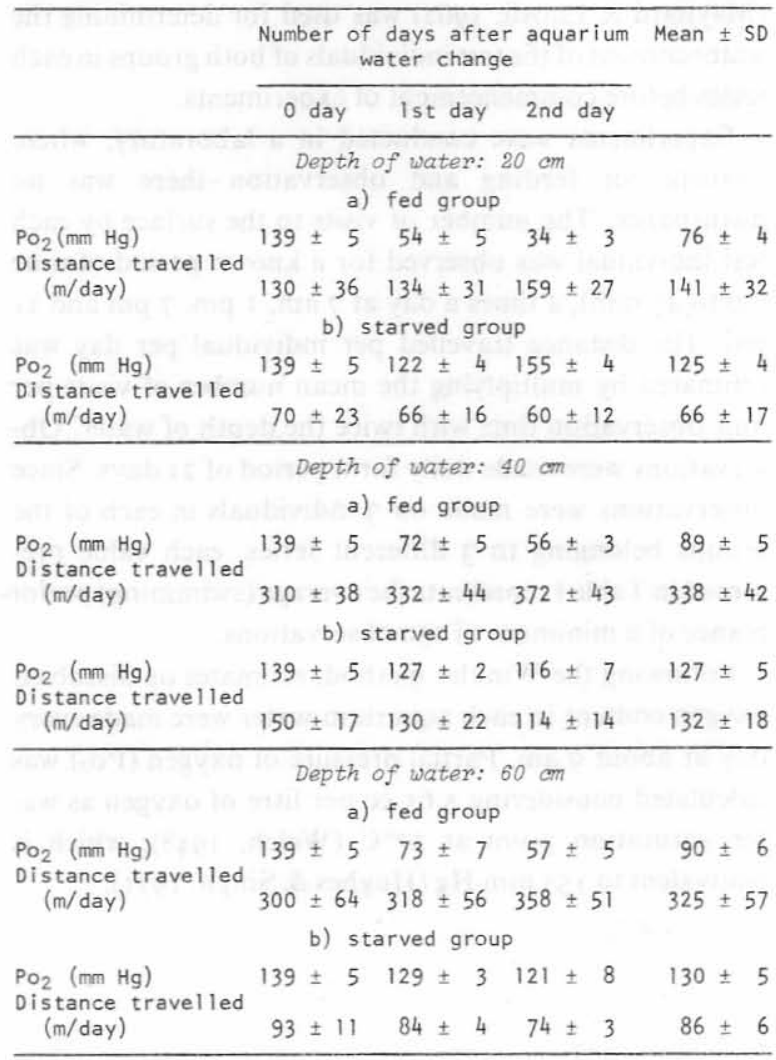

respectively. On the whole these groups were exposed to an average $\mathrm{PO}_{2}$ of $76,89,90 \mathrm{~mm} \mathrm{Hg}$. While the starving groups were exposed to an average $\mathrm{Po}_{2}$ of $128 \mathrm{~mm} \mathrm{Hg}$, the feeding groups were exposed to an average $\mathrm{Po}_{2}$ of only 85 $\mathrm{mm} \mathrm{Hg}$ (Table I). The significant decrease observed in the $\mathrm{Po}_{2}$ of aquarium containing feeding groups may be due to the decomposing faeces.

\section{Surfacing response as function of $\mathrm{PO}_{2}$}

Hughes \& Singh (I97I) observed that when H. fossilis is kept in air-saturated water, it rarely surfaced, remaining under the surface for a maximum period of $12 \mathrm{hr}$. The fish attempted surfacing when the $\mathrm{PO}_{2}$ was reduced between 100 and $50 \mathrm{~mm} \mathrm{Hg}$. Such changes in the $\mathrm{PO}_{2}$ decreased the $\mathrm{O}_{2}$ uptake from 0.06 to $0.04 \mathrm{ml} / \mathrm{g} / \mathrm{hr}$ at $25^{\circ} \mathrm{C}$. In the present study, feeding and starving $H$. fossilis exposed to different depths of aquaria, began to surface usually after an hour of water change in the aquarium, i.e. at $27^{\circ} \mathrm{C}$, the fish commenced surfacing even at the $\mathrm{Po}_{2}$ of about 140 $\mathrm{mm} \mathrm{Hg}$. The feeding group exposed to $20 \mathrm{~cm}$ depth surfaced 326 times/day (Fig. I) and swam I $30 \mathrm{~m} /$ day (Table I) on the $\mathrm{O}$ day, when the $\mathrm{Po}_{2}$ was $139 \mathrm{~mm} \mathrm{Hg}$; despite the decrease in the $\mathrm{Po}_{2}$ to $54 \mathrm{~mm} \mathrm{Hg}$ the fish did not significantly increase the number of surfacing on the Ist day; on the 2nd day, when the $\mathrm{Po}_{2}$ was only $34 \mathrm{~mm} \mathrm{Hg}$, the fish, however, increased surfacing to 398 times/day. Similarly, the feeding groups in 40 and $60 \mathrm{~cm}$ depths did

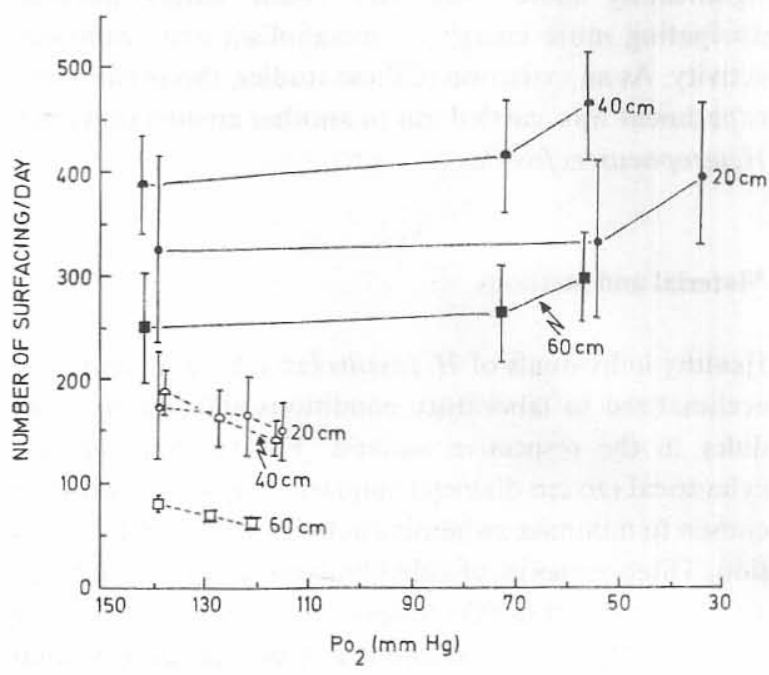

Fig. 1. Effects of the $\mathrm{Po}_{2}$ on the number of surfacing by the feeding (continuous lines) and starving (dotted lines) Heteropneustes fossilis exposed to $20 \mathrm{~cm}(-0-), 40 \mathrm{~cm}(-)$ and $60 \mathrm{~cm}$ (घ) water depths at $27^{\circ} \mathrm{C}$. Each value represents the average performance of minimum 3 individuals (mean $\pm \mathrm{SD}$ ) observed on 7 different dates for a period of 3 hours / day. 
not significantly increase the number of surfacing on the Ist day (Fig. I), despite the decrease in the $\mathrm{Po}_{2}$ to $72 \mathrm{~mm}$ $\mathrm{Hg}$. On the 2nd day, when the $\mathrm{Po}_{2}$ averaged only $56 \mathrm{~mm}$ $\mathrm{Hg}$, these groups increased significantly the number of surfacing to 465 and 298 times/day, respectively (Fig. I). It therefore appears that the decreasing $\mathrm{Po}_{2}$ induces the feeding groups to surface more frequently beyond $70 \mathrm{~mm}$ $\mathrm{Hg}$. Response of the starving groups to the decreasing $\mathrm{Po}_{2}$ was, however, different. As the $\mathrm{Po}_{2}$ decreased to about $\mathrm{I} 26$ and $\mathrm{II} 7 \mathrm{~mm} \mathrm{Hg}$ on the Ist and 2nd day, the number of surfacing linearly decreased in all groups (see Fig. I).

\section{Surfacing and swimming activities}

Despite these day-to-day variations in the $\mathrm{Po}_{2}$ and the consequent differences in the surfacing response of the feeding and starving groups exposed to different depths, certain trends became apparent in relation to ration levels and aquarium depths, when the data obtained for the number of surfacing and the distance travelled per day as function of time (2I days) are considered. Table II presents data on the effects of different water depths on swimming activity of the feeding and starving groups. The number of surfacing increased from 353 times/day, when the feeding groups were reared in aquarium containing 20 $\mathrm{cm}$ depth of water to 423 times/day in those fish at a depth of $40 \mathrm{~cm}$ and correspondingly, the distance travelled also increased from 141 to $338 \mathrm{~m} /$ day. However, the group reared in $60 \mathrm{~cm}$ depth of water reduced the number of surfacing to $27 \mathrm{I}$, swimming only $325 \mathrm{~m} /$ day. The starving groups surfaced only 163 times/day and travelled 65 or
$130 \mathrm{~m} /$ day, when reared in 20 or $40 \mathrm{~cm}$ depth of water. Like the feeding groups exposed to $60 \mathrm{~cm}$ depth of water, the starving group significantly reduced the number of surfacing to 70 times and the distance travelled to $84 \mathrm{~m} /$ day.

On the whole, it appears that feeding and starving $H$. fossilis reduced the number of surfacing, when the distance they have to swim exceeded $0.8 \mathrm{~m} /$ surfacing and increased the proportion of oxygen uptake branchially (see Table II). Pandian \& Vivekanandan (1976) observed that the obligatory air-breathing fish Ophiocephalus striatus progressively increased the surfacing and the distance swam, when they were exposed to deeper and deeper aquaria. After swimming a definite distance, O. striatus resorted to a behavioural adaptation of 'hanging' to the surface $(3.0 \mathrm{hr}$ for the feeding groups and $15.5 \mathrm{hr}$ for the starving groups) for a definite period of time before returning to the bottom; in addition to the branchial respiration, 'hanging' to the surface permitted $O$. striatus to exchange gas without undertaking vertical migration. $\mathrm{Ob}-$ viously $O$. striatus, as an obligatory air-breathing fish, is not able to alter the proportion of $\mathrm{O}_{2}$ uptake from water and air. H. fossilis, as a facultative air-breather, attempts to maintain the proportion of $\mathrm{O}_{2}$ uptake from water and air upto a limit, in which the energy cost involved in swimming does not exceed $0.8 \mathrm{~m} /$ surfacing, and beyond that it alters the proportion of $\mathrm{O}_{2}$ uptake more in favour of branchial respiration. Hughes \& Singh (I97I) reported that $H$. fossilis obtained $59 \%$ of its requirements from water and $4 \mathrm{I} \%$ from air, and has considerable powers of

Table 2. Effects of feeding, starvation and surfacing activity on different metabolic parameters in Heteropneustes fossilis. Each value represents the average performance of minimum 3 individuals (mean $\pm \mathrm{SD}$ ) observed for a period of 21 days at $27^{\circ} \mathrm{C}$.

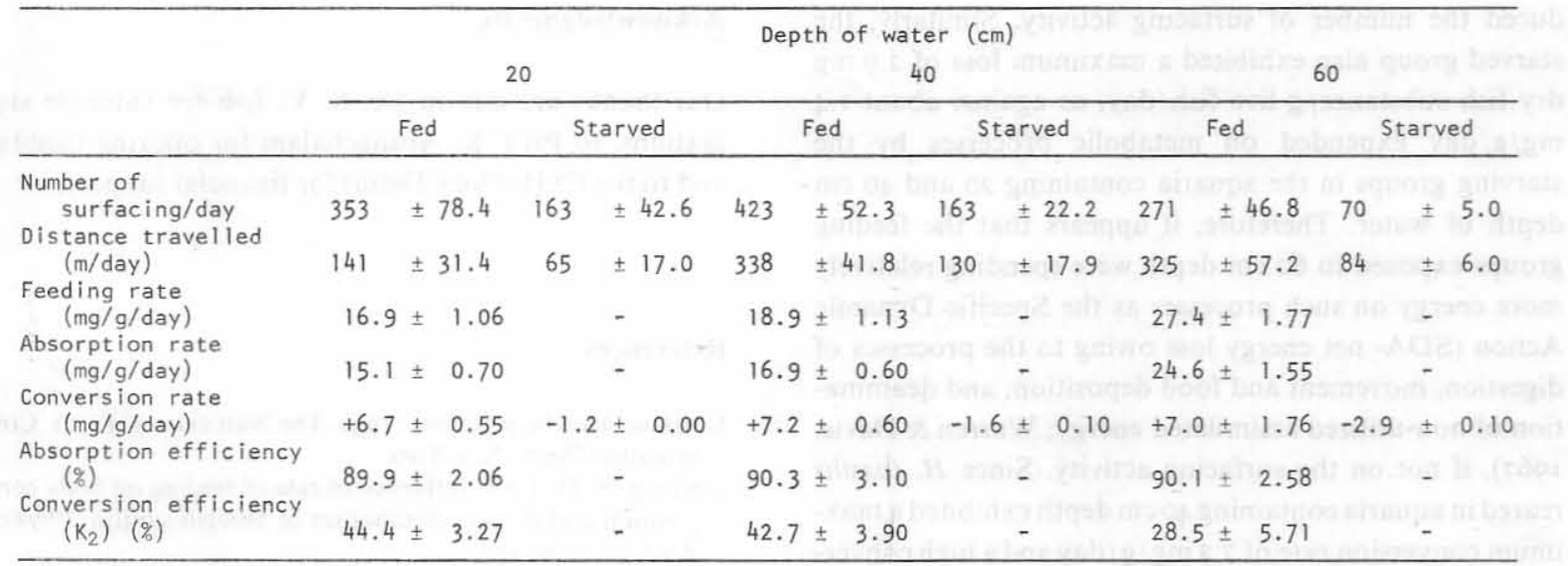


reversing the proportion when exposed to different environmental stress.

\section{Rates of feeding and conversion}

Feeding rate, which was about $18 \mathrm{mg}$ dry liver/g live fish/day in the groups exposed to 20 and $40 \mathrm{~cm}$ depth, increased significantly to $27.4 \mathrm{mg} / \mathrm{g}$ /day in the group reared in the maximum depth. Difference in the feeding rates among the groups exposed to 20 and $40 \mathrm{~cm}$ depth was not statistically significant $(\mathrm{t}=\mathrm{I} .29 \mathrm{I} ; \mathrm{P}<0 . \mathrm{IO})$; the same is true with regard to number of surfacing. Food absorption efficiency averaged $90.1 \%$ and did not appreciably vary between these groups, despite the more than $50 \%$ increase in the ration consumed by the group reared in $60 \mathrm{~cm}$ depth aquaria (see also Gerking, 1955, 1971; Pandian, 1967; Pandian \& Vivekanandan, 1976, Vivekanandan, 1976); hence the trend observed for absorption rate as function of depth of water and ration is parallel to the one obtained for feeding rate against depth of water.

Conversion efficiency $\left(\mathrm{K}_{2}\right)$ was about $43 \%$ in the groups exposed to 20 and $40 \mathrm{~cm}$ depth and the observed difference among them was not statistically significant $(\mathrm{t}=$ $0.475 ; \mathrm{P}<0.10$ ). The $43 \%$ efficiency is one of the highest values so far reported. The other high values reported in the literature are $37 \%$ for the yearling cutthroat trout Salmo clarkii (Warren \& Davis, 1967), 44\% (Pandian, 1967), 35\% (Vivekanandan et al., 1976) for the young (I g) $O$. striatus fed on prawn or goat liver. Values from the Cortland Hatchery Reports (I952) for the trouts fed on different combinations of cattle liver, also suggest such high values.

$H$. fossilis, reared in $60 \mathrm{~cm}$ depth aquaria, however, showed significantly low conversion efficiency of $28.5 \%$, although they consumed significantly more food and reduced the number of surfacing activity. Similarly, the starved group also exhibited a maximum loss of $2.9 \mathrm{mg}$ dry fish substance/g live fish/day, as against about $\mathrm{I} .4$ $\mathrm{mg} / \mathrm{g} /$ day expended on metabolic processes by the starving groups in the aquaria containing 20 and $40 \mathrm{~cm}$ depth of water. Therefore, it appears that the feeding groups exposed to $60 \mathrm{~cm}$ depth were spending relatively more energy on such processes as the Specific Dynamic Action (SDA- net energy loss owing to the processes of digestion, movement and food deposition, and deamination of non-utilized assimilated energy; Warren \& Davis, 1967), if not on the surfacing activity. Since $H$. fossilis reared in aquaria containing $40 \mathrm{~cm}$ depth exhibited a maximum conversion rate of $7.2 \mathrm{mg} / \mathrm{g} /$ day and a high conver- sion efficiency of $42.7 \%$, cultivation in shallow waters of $40 \mathrm{~cm}$ depth may promote efficient and rapid growth.

\section{Summary}

Reared in tubular aquaria containing 20,40 and $60 \mathrm{~cm}$ depth of water, Heteropneustes fossilis ( $20 \mathrm{~g} ; 17 \mathrm{~cm}$ body length), an air-breathing catfish, swam 40,80 and 120 $\mathrm{cm} /$ surfacing to exchange atmospheric air. With decreasing $\mathrm{Po}_{2}$, the starving groups reduced the surfacing, whereas, the decrease in the $\mathrm{Po}_{2}$ beyond $70 \mathrm{~mm} \mathrm{Hg}$ induced the feeding groups to surface more frequently. Feeding groups exposed to 20 and $40 \mathrm{~cm}$ depth surfaced 353 and 423 times, travelling distances of $\mathrm{I} 4 \mathrm{I}$ and 338 $\mathrm{m} /$ day, at the energy cost of 8.5 and $9.7 \mathrm{mg}$ dry fish substance/g live fish/day, respectively. The corresponding starving groups surfaced only 163 times/day and swam 65 and $130 \mathrm{~m} /$ day at the expense of 1.2 and $1.6 \mathrm{mg} / \mathrm{g} /$ day. Feeding and starving groups reduced the number of surfacing, when the distance they have to swim exceeded 0.8 $\mathrm{m} /$ day and increased the proportion of $\mathrm{O}_{2}$ taken up branchially; the starving and feeding groups exposed to $60 \mathrm{~cm}$ depth surfaced only 70 and 271 times, swimming 84 and $325 \mathrm{~m} /$ day, at the energy cost of 2.9 and $17.6 \mathrm{mg} / \mathrm{g} /$ day. Feeding and conversion rates steadily increased from 16.9 $\mathrm{mg}$ dry liver/g live fish/day and $6.7 \mathrm{mg}$ dry fish substan$\mathrm{ce} / \mathrm{g}$ live fish/day in those exposed to the shallowest aquarium to $27.4 \mathrm{mg} / \mathrm{g} /$ day and $7.0 \mathrm{mg} / \mathrm{g} /$ day in those exposed to the maximum depth, respectively; conversion efficiency was $44 \%$ in the former and $28 \%$ in the latter; hence culturing $H$. fossilis in the shallow waters is profitable.

\section{Acknowledgments}

Our thanks are due to Dr. S. V. Job for valuable suggestions, to Prof. K. Arunachalam for offering facilities and to the CSIR (New Delhi) for financial support.

\section{References}

Cortland Hatchery Report. 1952. The Nutrition of Trout. Conservation Dept., New York.

Gerking, S. D. 1955. Influence of rate of feeding on body composition and protein metabolism of bluegill sunfish. Physiol. Zool. 28: 267-282. 
Gerking, S. D. 1971. Influence of rate of feeding and body weight on protein metabolism of bluegill sunfish. Physiol. Zool. 44: 9-19.

Hughes, G. M. \& Singh, B. N. 197I. Gas exchange with air and water in an air-breathing catfish, Saccobranchus (= Heteropneustes) fossilis. J. Exp. Biol. 55: 667-682.

Johansen, K. 1970. Air-breathing in fishes, Vol. IV, pp. 36I-4I I in W. S. Hoar \& D. J. Randall (Editors). Fish Physiology. Academic Press, New York.

Maynard, A. L. \& Loosli, K. J. I962. In Animal Nutrition p. 533 McGraw-Hill, New York.

Pandian, T. J. 1967. Intake, digestion, absorption and conversion of food in fishes Megalops cyprinoides and Ophiocephalus striatus. Mar. Biol. I: 16-32.

Pandian, T. J. \& Vivekanandan, E. 1976. Effects of feeding and starvation on growth and swimming activity in an obligatory air-breathing fish. Hydrobiologia 49: 33-39.

Vivekanandan, E. 1976. Effects of feeding rate on swimming activity and growth in the tropical fish Ophiocephalus striatus. J. Fish Biol. 8: 32 I-330.

Vivekanandan, E., Easwari, P.\& Pandian, T. J. 1976. Effects of food quality on swimming activity and food utilization in the air-breathing fish Ophiocephalus striatus. Pol. Arch. Hydrobiol. (in press).

Warren, C. E. \& Davis, G. E. 1967. Laboratory studies in the feeding, bioenergetics and growth of fish, pp. 175-214 in S. D. Gerking (Editor). The Biological Basis of Freshwater Fish Production. Blackwell Scientific Publications, Oxford.

Welch, P. S. 1948. Limnological methods. p. 38 I, McGraw - Hill, New York. 